\title{
Caito v. United California Bank: Accommodation Maker Liability in Foreclosure Sales
}

The Caitos, cotenants of a parcel of farm property, sought a declaration of the rights of all parties claiming an interest in the land. ${ }^{2}$ Joined in the action were the Caponis as the reinaining cotenants, Bank of America as the beneficiary of a first trust deed in which both the Caitos and the Caponis appeared as principals, and United Cahfornia Bank (UCB) as the beneficiary of a second trust deed executed by the Caponis on their one-half interest in the property without the knowledge of the Caitos. ${ }^{3}$ While the action was pending, the property was sold following the nonjudicial foreclosure of the senior trust deed. Proceeds of the sale totaled $\$ 130,000$. Bank of America retained approxiinately $\$ 44,500$ in satisfaction of its claim, deposited the $\$ 85,500$ reinainder with the court, and was dismissed froin the action.

Both the Caitos and UCB contended that they were entitled to the Caponis' entire share of the surplus froin the foreclosure. The Caitos argued that they had signed the Bank of Ainerica note' as accoinmodation inakers only. ${ }^{4}$ The senior lien therefore should be satisfied wholly fron the Caponis' $\$ 65,000$ share of the sale proceeds, leaving the Caitos' one-half interest untouched. The Caitos also asserted equitable hens against the remainder of the Caponis' interest. These liens were based on advances of approximately $\$ 6,000$ made in early 1967 to the Caponis for the purpose of allowing thein to keep the Bank of America note current, ${ }^{5}$ and on a payinent of $\$ 17,500$ made directly to Bank of

1. 20 Cal. 3d 694, 576 P.2d 466, 144 Cal. Rptr. 751 (1978) (Clark, J.) (unanimous decision).

2. The Caitos and the Capomis owned the property, a Calexico farm, as equal cotenants from 1952 to 1973 . The Caitos lived in Indiana and the Caponis managed the farm until after Mr. Caponi suffered a stroke in 1967. Caito v. United Cal. Bank, 137 Cal. Rptr. 842, $843-44$ (1977) (opinion deleted $69 \mathrm{Cal}$. App. 3d 161). The Caitos and Caponis were not partners in the farming business but only co-owners of the property.

3. 137 Cal. Rptr.' at 842 .

The Caponis lad become indebted to UCB in an amount approximating $\$ 140,000$. The debt was secured by three first trust deeds on other Caponi property. In December 1967, UCB dcmanded payment and the Caponis were unable to meet the demand. UCB agrced to forbear lcgal action in return for a second deed of trust on the Caponis' one-half interest in the farm. The agreement was executed and the trust deed recorded, without the knowledge or consent of the Caitos. The Bank of America deed was already of record at the time.

4. An accommodation party is one who signs a negotiable instrument for the purpose of lending his or ler name to another party to it. CAL. COM. CODE $\S 3415$ (West 1964). See notes 19-21 and accompanying text infra.

5. The court notes that of the $\$ 6,000$ advanced in 1967 , only $\$ 3,232.94$ actually was applied 
America in 1968. UCB, on the other hand, argued that the equitable claims of the Caitos must be subordinate to the junior lien because that lien was created without notice of the equitable claims.

The trial court determined that the Caitos were liable on the Bank of America note as accommodation inakers only, despite their apparent status as principals. ${ }^{6}$ It therefore held that the Bank of America note should be satisfied first out of the Caponis' half interest in the sale proceeds. $^{7}$ The trial court also held that the Caitos were entitled to equitable lien riglits with priority over UCB to the extent of the $\$ 6,000$ advanced in 1967 and the $\$ 17,500$ payment inade in $1968 .^{8}$ These equitable liens exhausted the remainder of the Caponis' interest in the sale proceeds, whicl meant that the Caitos took the entire $\$ 85,500$ surplus and UCB took nothing. ${ }^{9}$

The court of appeal reversed. The court agreed with the trial court's determination that the Caitos were accommodation makers. ${ }^{10}$ It nevertlieless applied the Caito and Caponi interests equally in satisfaction of the Bank of America note, allowing the UCB claim to the extent of one-lialf the amount deposited with the trial court. ${ }^{11}$ Additionally, the court subordinated the Caitos' equitable claims to the junior notes held by UCB. ${ }^{12}$ The court acknowledged that the payments made by the Caitos gave rise to equitable liens against the Caponis' interest, ${ }^{13}$ but held that such liens are subordinate to the claims of a bona fide encumbrancer for value without notice of the prior interests. The net result was that the Caponis' share of the surplus proceeds was

to the Bank of America note. $20 \mathrm{Cal} .3 \mathrm{~d}$ at $699 \mathrm{n} .1,576$ P.2d at $468 \mathrm{n} .1,144 \mathrm{Cal}$. Rptr. at $753 \mathrm{n} .1$. According to the court of appeal, the Caitos advanced an additional $\$ 3,500$ in 1968, of which $\$ 1,183.86$ was applied to the senior note. $137 \mathrm{Cal}$. Rptr. at 844 . The Caitos asserted that they had loaned at least an additional $\$ 10,000$ to the Caponis for various operating expenses, and that they had never received any rents or profits. They made no claim, however, based on either the loans or rents. Id. at 842; Respondent's Brief at 4-5.

6. $20 \mathrm{Cal} .3 \mathrm{~d}$ at 699,576 P.2d at $468,144 \mathrm{Cal}$. Rptr. at 753 . In 1959, in order to enable the Caponis to borrow money, both couples signed a $\$ 30,000$ note in favor of Bank of America secured by a first deed of trust on the farm property. In 1965 , both executed a new note and trust deed to Bank of America for $\$ 40,000$. The Caponis used part of the proceeds of this loan to pay the balance on the earher note and retained the remainder. Although the Caitos appeared as principals on both notes, the trial court concluded they signed the documents on both occasions as an accommodation to the Caponis. They received no part of the proceeds from either loan. 137 Cal. Rptr. at 844-45.

7. 20 Cal. $3 d$ at 700,576 P.2d at 468-69, 144 Cal. Rptr. at 753-54.

8. Id.

9. Id. at 699-700, 576 P.2d at 468-69, 144 Cal. Rptr. at 753-54.

10. 137 Cal. Rptr. at 845 .

11. Id. at 847 .

12. Id. at $846-47$.

13. Id. at 845. See Willmon v. Koyer, 168 Cal. 369, 143 P. 694 (1914). See also M. OGDEN, 2 California Real Property Law § $19-4$ (rev. ed. 1974) [heremafter cited as OGDeN]. 
fixed at approximately $\$ 42,750$, all of which was applied to UCB's junior note. The Caitos were left with a like amount.

The supreme court affirmed the court of appeal's decision, relying on a slightly different analysis. The court stated that the Caitos' accommodation maker status could be proved as against the Caponis, but it refused to allow such proof as against either Bank of America or UCB. ${ }^{14}$ The court therefore held that the Caitos were equally liable with the Caponis as principals on the Bank of America note. ${ }^{15}$ This again ineant that the size of the surplus attributable to the Caponis' interest, the only fund against which UCB could claim in satisfaction of its junior note, ${ }^{16}$ was fixed at $\$ 42,750$. As to the equitable lien rights asserted by the Caitos, the court concluded that even if such rights existed, they could not be given priority over the rights of UCB, a subsequent encumbrancer for value without notice. ${ }^{17}$ As to the equitable lien asserted as a result of the $\$ 17,500$ payment, the court further found that the money used to make the payment was derived from rents and profits of the farm expressly assigned to Bank of America under the first trust deed. The court held that the Caitos had collected the inoney as agents of Bank of America, thereby preventing any equitable lien rights from arising in the first instance. ${ }^{18}$

This Note argues that the supreme court was not justified in reversing the two lower courts' factual determination that the Caitos were liable as accommodation makers only. The court obviously sought to protect the integrity of the recording system. Its refusal to allow the Caitos to prove their actual status as against Bank of America and $\mathrm{UCB}$, lowever, was based on an unprecedented and unwarranted application of Civil Code section 2832. Furthermore, it contravened the elaborate statutory and common law protections afforded sureties ${ }^{19}$ and ignored commercial reality. The court's opinion confuses the law of suretyship in relation to the rights of a bona fide purchaser under the recording acts. This Note concludes that had the court correctly acknowledged the Caitos' accommodation maker status, and in so doing confronted the tension between suretyship law and the recording acts, it

14. 20 Cal. 3d at $700-01,576$ P.2d at 469,144 Cal. Rptr. at 754 .

15. Id.

16. When a cotenant separately encumbers its interest in jointly owned property, as it may without knowledge or consent of other cotenants, the encumbrance attaches only to that cotenant's interest. Haster v. Blair, 41 Cal. App. 2d 896, 898, 107 P.2d 933, 934 (1940).

17. 20 Cal. 3d at 706,576 P.2d at 473,144 Cal. Rptr. at 758.

18. Id. According to the court of appeal, Mr. Caito collected $\$ 17,500$ in rent between July 1968 and August 1970, paying the total to Bank of America. After August 1970, when Bank of America refused to accept further payments, he collected $\$ 6,275.15$ before the foreclosure sale, which he retained. $137 \mathrm{Cal}$. Rptr. at 844.

19. An accoinmodation maker is a surety. California Code Comment to CAL. COM. CODE $\$ 3415$ (West 1964). See notes 33-38 and accompanying text infra. 
would have satisfied the Bank of America note wholly from the Caponis' interest in the sale proceeds, and recognized and given priority to one-half of the $\$ 17,500$ equitable lien.

ANALYSIS

\section{A. The Caitos Were Entitled to Prove Their Status as Accommodation Makers on the Senior Encumbrance}

It is unclear why the supreme court refused to accept the lower courts' factual finding that the Caitos were accommodation makers. The court apparently believed that Civil Code section 2832 operates as a legal bar to the introduction of extrinsic evidence on this issue as against either Bank of America or UCB, and that the lower courts' imclusion of such evidence was a reversible error of law. ${ }^{20}$ If this is imdeed the court's reasoning, it is objectionable on two grounds. First, it represents an expanded apphication of section 2832 that is unwarranted im light of previous judicial interpretations and legislation post-dating the enactment of section 2832. Second, it presumes that Bank of America and UCB "acted on the faith of [the Caitos'] apparent character as principal," as section 2832 requires. This presumption ignores commercial reality and the failure of either Bank of America or UCB to contend that the Caitos were not accommodation makers. ${ }^{21}$

The Caito court's construction of Civil Code section 2832 is unprecedented. Civil Code section 2832 provides: "One who appears to be a principal, whether by the terins of a written imstrument or otherwise, nnay show that he is in fact a surety, except as against persons who have acted on his apparent character of principal."22 Prior to Caito, the final clause of this section was not extended to protect a party who had not made a claim directly against the surety or on the instrument. ${ }^{23}$

20. $20 \mathrm{Cal} .3 \mathrm{~d}$ at $701,576 \mathrm{P} .2 \mathrm{~d}$ at $469,144 \mathrm{Cal}$. Rptr. at 754 . The court of appeal stated that "[t]he evidence establishes without conflict that the Caitos were, in fact, accommodation makers on the B of A note, and that other equitable adjustinents arising out of their relationship as cotenants in the property more than accounted for their half-interest in the $\$ 130,000$ for which the property was sold." 137 Cal. Rptr. at 845 . The supreine court did not discuss the sufficiency of the evidence under the clearly erroneous standard, or at all. Froin this the author concludes that the supreme court found the lower courts wrong as a matter of law.

21. In its briefs to the court of appeal and the supreme court, UCB never contested the Caitos' accommodation maker status. On the contrary, it acknowledged that status and referred to Caito as a "secret accommodation maker." Caito v. United Cal. Bank, 20 Cal. 3d 694, 576 P.2d 466, 144 Cal. Rptr. 751 (1978); Brief for Appellant at 8, 14, 16. It does seem clear, however, that UCB had no actual knowledge of the Caitos' status at the time of the agreemeut between UCB and the Caponis. Bank of America was not a party to the action.

22. CAL. Crv. Code $\S 2832$ (West 1974).

23. See, e.g., Sanders v. Magill, 9 Cal. 2d 145, 70 P.2d 159 (1937) (assignee of note); Granger v. Harper, 217 Cal. 16, 17 P.2d 135 (1933) (payee lender); McCarthy v. Madison, 190 Cal. 243, 212 
Legislation post-dating the enactment of Civil Code section 2832 raises further questions about the court's imterpretation. Section 2832 was enacted before the adoption of either the Uniform Negotiable Instruments $\mathrm{Law}^{24}$ or its successor, division three of the Commercial

P. 7 (1922) (payee on note); Figari v. Olcese, 184 Cal. 775, 195 P. 425 (1921) (payee lender); Daneri v. Gazzola, 139 Cal. 416, 73 P. 179 (1903) (payee lender); Farmers' and Merchants' Bank v. De Shorb, 137 Cal. 685, 70 P. 771 (1902) (payee lender); Casey v. Gibbons, 136 Cal. 368, 68 P. 1032 (1902) (beneficiary of mortgage); Eppinger v. Kendrick, $114 \mathrm{Cal} .620,46$ P. 613 (1896) (payee on note); O'Conor v. Braly, 112 Cal. 31, 44 P. 305 (1896) (assignee holder of note); Cạlifornia Nat'l Bank v. Ginty, 108 Cal. 148, 41 P. 38 (1895) (payee on note); Montgomery v. Sayre, 91 Cal. 206, 27 P. 648 (1891) (payee on note); San Bernadino Nat'l Bank v. Colton, 91 Cal. 124, 27 P. 538 (1891) (assignee of note); Southern Cal. Nat'l Bank v. Wyatt, 87 Cal. 616, 25 P. 918 (1891) (payee on note); Chafoin v. Rich, 77 Cal. 476, 19 P. 882 (1888) (payee on note); Leeke v. Hancock, 76 Cal. 127, 17 P. 937 (1888) (payee taker who became subsequent endorser of note); Farmer's Nat'l Bank v. Stover, 60 Cal. 387 (1882) (payee lender); Harlan v. Ely, 55 Cal. 340 (1880) (payee lender); Wexler v. McLucas, 48 Cal. App. 3d Supp. 9, 121 Cal. Rptr. 453 (1975) (payee on contract of sale); Beverly Hills Nat'l Bank v. Glynn, 267 Cal. App. 2d 859, 73 Cal. Rptr. 808 (1968), appeal after remand, 16 Cal. App. 3d 274, 93 Cal. Rptr. 907 (1971) (payee on note and guaranty); Matthews v. Hinton, 234 Cal. App. 2d 736, 44 Cal. Rptr. 692 (1965) (payee lender); Palm Springs S. \& S., Inc. v. Bering, 213 Cal. App. 2d 177, 28 Cal. Rptr. 526 (1963) (payee on note securing chattel mortgage); Garrett v. Bomash, 10 Cal. App. 2d 288, 51 P.2d 1100 (1935) (holder in due course of note); Josephian v. Lion, 66 Cal. App. 650, 227 P. 204 (1924) (assignee of payee on note); First Nat'l Bank of Escondido v. Williams, 54 Cal. App. 537, 202 P. 164 (1921) (payee lender); Good v. Brown, 40 Cal. App. 753, 181 P. 802 (1919) (beneficiary of mortgage); Wolf v. Brakebill, 32 Cal. App. 300, 162 P. 918 (1916) (payee on note); Osborn v. Hamilton, 16 Cal. App. 634, 117 P. 786 (1911) (payee on note).

The rule before enactment of Civil Code $\$ 2832$ was to hold an apparent principal liable in all cases. Shriver v. Lovejoy, 32 Cal. 574 (1867). Aud v. Magruder, 10 Cal. 282 (1858), stated the rule that one who is an accommodator as between payors is not necessarily sueh as to the creditor. Following adoption of $\S 2832$, the rule was amended. Showing the creditor's knowledge of accommodation status, however, was held insufficient to establish suretyship as against the creditor-the accominodator was also required to show that the creditor had consented to accept the party's liability as surety only. Leeke v. Hancock, 76 Cal. 127, 17 P. 937 (1888); Farmer's Nat'1 Bank v. Stover, 60 Cal. 387 (1882); Osborn v. Hamilton, 16 Cal. App. 634, 117 P. 786 (1911).

In 1939, the following sentence was added by amendment to $\$ 2832$ : "It is not necessary for [the accommodating party] to show that the creditor accepted him as surety." CAL. Civ. CODE $\S 2832$ (West 1974). While this amendment would appear to mean that actual reliance on the apparent character of an accommodation party is the key issue, as to which the burden of proof would therefore be borne by the relying party, the courts have not so construed it. Instead, they seem inore concerned with whether the accommodating party's behavior was consistent with an intent to be helpful and a belief that it was only secondarily hable on the debt. The cases appear to focus on the reasonableness of a creditor's rehance rather than emphasizing actual reliance. See, e.g., Wexler v. McLucas, 48 Cal. App. 3d Supp. 9, 121 Cal. Rptr. 453 (1975) (where mother "co-signed" for son and agreed to pay for furniture only if he failed to do so, seller's intent that she be bound as purchaser on contract of sale not controlling); Beverly Hills Nat'l Bank v. Glynn, 267 Cal. App. 2d 859, 73 Cal. Rptr. 808 (1968) (attorney-guarantor who procured loans for another and gave own notes and a continuing guaranty as security dealt directly with lending bank); Matthews v. Hinton, 234 Cal. App. 2d 736, 44 Cal. Rptr. 692 (1965) (owner-lessors of land who cosigned developer-lessees' note to construction lender held to have a direct financial interest in improvements thus financed, partly on grounds that they also exposed their reversionary interest by agreeing to subordinate title to any future construction loan as well).

24. Section 2832 was enacted im 1872. CaL. Civ. Code $\$ 2832$ (West 1974). The Negotiable Instruments Law was enacted in 1917. See 2 B. WITKIN, SUMMARY OF CALIFORNIA LAW 1293-95 (1973). 
Code. This subsequent legislation, inexplicably ignored by the Caito court, inandates a narrow interpretation of section 2832. Commercial Code section 3415(3) exphicitly states that an apparent principal may prove its surety status except as against a "holder in due course," defined in section $3302 .{ }^{25}$ The section 3302 definition arguably encompasses an even narrower class of parties than that encompassed by the pre-Caito case law under Civil Code section 2832. Transferees claiming on the negotiated instrument as holders in due course are still protected, but parties with a direct claim as payees of the instrument nay not be. ${ }^{26}$

Neither UCB nor Bank of America met the requirements for protection under section $2832 .{ }^{27} \mathrm{UCB}$ of course had no claim against the Caitos as a payee of the senior note or as a holder in due course of a negotiable imstrument. Under Commercial Code section 3415(3) or the traditionally narrow interpretation of Civil Code section 2832, the Caitos therefore were entitled to introduce extrinsic evidence to prove their accommodation maker status as against UCB. Similarly, it is hard to see how either UCB or Bank of America could be brought within the terms of Civil Code section 2832 even if the expansive application of that section urged by the court were acceptable. Under section 2832 the Caitos could be prevented from proving their accommodation maker status only if UCB or Bank of America had

25. A holder in due course is one who takes the instrument for value and in good faith and without notice that it is overdue or has been dishonored or of any defense against or claim to it on the part of any person. CAL. CoM. CoDE $\$ 3302$ (West 1964).

26. The California State Bar Committee describes as follows the effect of the adoption of the Commercial Code:

Under the Code as under the N[egotiable] I[nstruments] L[aw], a surety who signs a negotiable instrument as an accommodation maker for the party primarily hable on the transaction, would appear as a principal party. Therefore, he would have no suretyship defenses (such as extension of tine, etc.) against a holder in due course. But under the N.I.L., most courts, including those in Califoraia, loold that even as against one not a liolder in due course an accommodation inaker cannot rely upon a suretyship defense. [Fn:: 1 Witkin, Summary of California Law 616-617 (1960); Hawkland, Commercial Paper 92-93 (A.L.I. 1959).] Code sections 13415 [3415] and 13306 [3306] reject this view. They would permit parol proof of the accommodation character of a maker's signature except as against a holder in due course.

California Code Coinment to CAL. CoM. CoDE $\S 3415$ (West 1964) (emphasis added) ( $\$ 3306$ provides for defenses against one not a holder in due course who takes the instrument).

27. Bank of Ainerica had no claim as a holder in due course of its own note. Thus, to the extent Commercial Code $\$ 3415$ does narrow the class of persons protected under Civil Code $\S 2832$, the Caitos were entitled to prove their accommodation maker status as against Bank of America. Even if the scope of Civil Code $\S 2832$ was not so narrowed, so that Bank of America theoretically could be protected as the payee on the note, it is inconceivable that $\S 2832$ was intended to cover a situation such as this, wliere Bank of America clearly knew that the Caitos signed as sureties only. See note 6 supra and note 32 infra. In such circumstances, Bank of America could not contend that it relied on the Caitos being primarily liable before it extended credit. Thus, Bank of America does not come within the terms of even a broadly construed $\S 2832$. 
relied on their apparent principal status. It seems improbable that the banks did in fact so rely. ${ }^{28}$ That UCB failed to contest the accommodation maker issue in the lower courts is proof of this. ${ }^{29}$ In any event, reliance inust be reasonable. The banks were undoubtedly aware that an accommodation maker often will appear as a principal on a trust deed. ${ }^{30}$ UCB and Bank of America are sophisticated lending institutions that should have been put on inquiry notice as to the Caitos' status, ${ }^{31}$ particularly since they knew that the Caitos and Caponis were cotenants. ${ }^{32}$ Reliance on the Caitos' apparent principal status would necessarily have been unreasonable.

Thus, the supreme court's refusal to pernit the Caitos to prove that they were accommodation makers on the Bank of America note was unwarranted because it was based upon a questionable imterpretation of Civil Code section 2832 and because even under the court's interpretation neither Bank of Anerica nor UCB were eligible for that section's protection. The factual finding of the two lower courts on this issue should have been respected.

28. UCB held first trust deeds to three other pieces of Caponi property and agreed to forbear foreclosing against those properties in return for a second deed of trust against the Caponis' interest in the Calexico farm. See note 3 supra. It is apparent that UCB never inquired whether the Caitos signed the Bank of America note as principals or accoininodators. See note $32 \mathrm{infra}$. On such facts there is a strong inference that UCB simply acted carelessly rather than in reliance on the record.

29. See note 21 supra. UCB inade no argument as to the reasonableness of its reliance.

30. This is a well-known fact among commercial lenders.

31. See notes $41-42$ and accompanying text infra.

32. The court held that cotenancy is not a fact which calls for further inquiry, citing a Texas case and ignoring California precedent which inight well have led it to a different conclusion. In Del Giorgio v. Powers, 27 Cal. App. 2d 668, 81 P.2d 1006 (1938), a purchaser was charged with knowledge of the rights of cotenant partners in a mining claim and inining property because he overheard a discussion between the partners about the ore. He was charged with this knowledge even though he apparently had not seen the unrecorded written agreement establishing the cotenancy partnership. In that case there was no record, yet the purchaser was charged with "actual notice of sufficient facts . . . to put a prudent man upon inquiry as to precisely what [the cotenants'] rights were . . . 27 Cal. App. 2d at 679, 81 P.2d at 1012. The question probably should not be whether cotenancy in itself is a fact calling for further inquiry. Instead, knowledge of a cotenancy relation should be regarded as one factor among others to be considered in determining whether a prudent purchaser or lender inight be unreasonable in assuming there are no unrecorded agreeinents between cotenants. Taken in conjunction with UCB's awareness that an accommodating co-maker will appear as primcipal on the instrunent and the ease with which UCB could have determined the actual status of the Caitos, it would not be unreasonable to place a duty of inquiry on the lender. The Caitos state in Respondents' Brief at 19 that a simple inquiry either by UCB or Bank of America would have disclosed their true status. UCB did not dispute that it never inquired. Also, the Caitos state they advised UCB of their accommodation status in May 1968, five inonths after the execution of UCB's trust deed and over two years before Bank of America callcd for foreclosure. Petition for Hearing in the Supreme Court at 11. This is also undisputed by $\mathrm{UCB}$. 


\section{B. Surety Protection v. Notice Principles}

Under the California Commercial Code, a party who signs an instrument as an accommodation maker is a surety. ${ }^{33}$ Civil Code section 2850 entitles a surety to have the property of the principal obhigor stand as security apphed in payment of the debt before the creditor is allowed to proceed against the surety. ${ }^{34}$ If the surety is forced to pay all or a portion of the debt, it has recourse against the principal. ${ }^{35}$ A surety may require his creditor to proceed first agamst the principal ${ }^{36}$ and is entitled to the benefit of every security for the performance of the principal obligation held by the creditor. ${ }^{37}$ It is therefore clear that, $\mathrm{m}$ the absence of any junior encumbrance, the Caitos as sureties could have required Bank of America first to exhaust the Caponis' interest in the farm proceeds when the farm was sold to satisfy the semior note. Only in the event the Caponis' interest did not fully cover the indebtedness could the Caitos have been charged. ${ }^{38}$

33. CAL. COM. CODE $\$ 3415$ (West 1964). For other provisions governing suretyship in California, see CAL. Crv. Code $\$ \$ 2787-2854$ (West 1974).

34. CAL. CIV. CoDE $\$ 2850$ (West 1974) provides: "Whenever property of a surety is hypothecated with property of the principal, the surety is entitled to have the property of the principal first applied to the discharge of the obligation."

35. CAL. CIv. CODE $\$ 2847$ (West 1974).

36. Cal. Civ. Code $\S 2845$ (West 1974). See also H. Miller \& M. Starr, 1 Current LaW of California Real Estate $\S \S 3: 82,8: 84$ (rev. ed. 1975) [hereinafter cited as Miller \& STARR].

37. CAL. Crv. Code $\S 2849$ (West 1974).

38. It should be noted at this point that the suretyship protections available to the Caitos could not be overridden by any marshalling rights UCB might assert. Under Civil Code § 3433, a senior creditor with resort to multiple security for the same debt inay be forced by a junior creditor to take first from that property against which only the senior creditor has a lien. See McCarthy v. Kurkjian, 65 Cal. App. 569, 224 P. 1016 (1924). Under Civil Code § 2899(2), the junior creditor may require the senior creditor to resort first to the collateral against which there are the fewest subordinate liens. Although the question of how $\$ 2899(2)$ should be construed in relation to $\S 3433$ apparently has not arisen, California courts consistently construe the provisions together or cite thein indiscriminately in niarshalling cases.

Assuming for the moment that the Caitos were hable as principals on the Bank of America note, $\S \S 3433$ and 2899(2) therefore would allow UCB to force Bank of America to exhaust the Caitos' interest in the cotenancy, as collateral withont a subordinate hen, before turning to the Caponis' interest, as collateral subject to UCB's jumior note. The question thus becomes whether UCB can assert the same niarshalling rights against the Caitos-as-snreties as it could against the Caitos-as-principals. Stated more explicitly, the result depends on whether UCB's marshalling rights are superior to the Caitos' suretyship defenses.

California precedent is clear that in such a contest, the rights of the surety prevail. Marshalling is allowed only if it can be accomplished without jeopardizing the senior creditor's interest and without injustice to third parties. McCarthy v. Kurkjian, 65 Cal. App. 569, 224 P. 1016 (1924). See 2 Miller \& STARR, supra note 36, at 271. Courts will not apply inarshalling doctrine to prejudice a surety. McCarthy v. Kurkjian, 65 Cal. App. 569, 224 P. 1016 (1924); Raun v. Reynolds, 11 Cal. 14 (1858). See 2 Miller \& STARr, supra note 36, at 271; Annot., 135 A.L.R. 738 (1941). Two lines of reasoning support this rule. The first is based on the notion that the property of the surety is not a fund within the debtor's hands. In a fornahistic sense, the senior creditor therefore is said not to have multiple security. The second stems from the idea that the surety has a superior equity to that of the creditor seeking to invoke marshalling doctrine because 
The question arises whether this result must change with the addition of a junior encumbrancer who does not have notice that an apparent principal on the senior note is in fact a surety. The resolution of this question involves a conflict between the policies protecting sureties fron unwarranted primary liability and the policies of the recording acts that mandate the protection of encuunbrancers who rely in good faith on the record state of title. ${ }^{39}$ It is quite conceivable that had the Caito court explicitly confronted this tension it would have resolved the case in favor of UCB to protect the integrity of California's notice and recording scheme. But the facts of the case would have allowed the court to respect the Caitos' suretyship rights in a inanner consistent with accepted notice and recording principles, thereby safeguarding the recording system and at the same tinne achieving a inore equitable result.

A major purpose of the recording acts is to protect bona fide purchasers or encuunbrancers for value by giving thein notice of hens or other interests affecting title. ${ }^{40}$ Recordation is one ineans of providing such notice. But notice doctrine aims to protect the vahid interests of all parties to a transaction, including those of a party who fails to record. ${ }^{41}$ Failure to record is not necessarily a "fault," independent of circumstances. A subsequent purchaser or encumbrancer is not justified in relying on the state of the record if there are other facts of which he reasonably should be expected to take notice. There are numerous cases holding that there is a duty to inquire beyond the record where some fact should have aroused in the mind of a reasonable purchaser or encumbrancer a suspicion of interest(s) in conflict with the recorded interests. In these cases, if reasonable imquiry would have revealed a different state of affairs than that in the record, the party is charged with constructive notice of such state of affairs. ${ }^{42}$

a surety who pays the principal's debt is entitled to be subrogated to the senior creditor's rights to the extent of the payment so nuade. See Annot., 135 A.L.R. 738 (1941). Thus, if the Caito court had confronted any marshalling rights that UCB might have asserted, it nonetheless would have been led to the conclusion that the Caitos should prevail.

39. See CaL. Crv. Code § 1214 (West 1974).

40. See, e.g., Johnson, Purpose and Scope of Recording Statutes, 47 Iowa L. REv. 231 (1962); Philbrick, Limits of Record Search and Therefore of Notice, 93 U. PA. L. REv. 125 (1944).

41. Only pure "race" statutes, which render void any conveyance not recorded, protect recording alone. The California statute, CAL. CIv. CODE $\$ 1214$ (West 1974), is of the type generally referred to as "race-notice." See Johnson, supra note 40 . See also note 42 and acconipanymg text infra.

42. See, e.g., Bank of Mendocino v. Baker, 82 Cal. 114, 22 P. 1037 (1889); Olson v. Cornwell, 134 Cal. App. 419, 428, 25 P.2d 879, 883 (1933).

CAL. CIV. CODE $\$ 19$ (West 1974) has codified the common law rule: "Every person who has actual notice of circumstances sufficient to put a prudent man upon inquiry as to a particular fact, has constructive notice of the fact itself in all cases in which, by prosecuting such inquiry, he night have learned such fact." Whether infornation is sufficient to imply notice is a qucstion of fact. 
The interplay between the duties to give and to take notice is based on the parties' reasonable expectations under the particular circumstances. This is evidenced by the rule that an instrument is binding on the parties thereto regardless of recordation. ${ }^{43}$ They obviously have notice of their agreement, thus their reasonable expectations do not depend on the formal giving or taking of notice.

The Caito court held that UCB was justified in relying on the record. ${ }^{44}$ It is difficult to believe, however, that UCB did in fact rely on the Caitos' apparent primcipal status. ${ }^{45}$ From the standpoint of ensuring accurate records, it might be argued that the court's resolution of the issue is proper because the Caitos were best situated to clarify the record as to their true status. ${ }^{46}$ It would certainly be simple for accoininodation parties to thus clarify the record if they were sophisticated enought to foresee that a third party might rely on their apparent primcipal status. But cosigners often are ordinary people witlout legal knowledge or sophistication in financial matters-it is not reasonable to expect them to foresee reliance by unknown third parties.

UCB, on the other liand, undoubtedly was aware that an accomnodation party often will appear as a primcipal on a trust deed. It is the business of a lending institution to know such things. Furtliermore, the finance industry is inost responsible for the fact that accommodation parties often appear as primcipals on an instrument because its members generally have the imstrument drawn to their specifications. Lending institutions are thus in the best position to eliminate any ambiguities. It would promote simplicity to require that a provision appear on the instrument whicls allows a party to clarify its status. Though the court cannot require this, it can encourage such a result by lolding that a third party likely to be aware of the problem - such as a sophisticated lender-has a duty to inquire whether the instrument reflects a cosigner's true status. Unfortunately, the court's holding probably has the effect of perpetuating the problem. Meinbers of the lending industry have no incentive to correct the ambiguity of a cosigner's status because they stand to profit from the fault in the record.

Even if UCB's reliance on the record were justified, the difficulty in Caito is not that a party failed to record, but that the record failed to reflect the true status of the property. This is analogous to cases where a substantial interest in land is not reflected in the record chain of ti-

Keese v. Beardsley, 190 Cal. 465, 474, 213 P. 500, 503 (1923). See also 42 CAL. Jur. 2d, Records and Recording Laws $\$ \S 58-60$ (1958).

43. Cal. Crv. Code $\& 1217$ (West 1974).

44. $20 \mathrm{Cal}$. 3d at $702,576 \mathrm{P} .2 \mathrm{~d}$ at $470,144 \mathrm{Cal}$. Rptr. at 755 .

45. See notes 28-32 and accompanying text supra.

46. The Caitos need only have noted on the Bank of America note and trust deed that they signed as accommodation makers. 
tle. ${ }^{47}$ A typical example is when a common grantor deeds land by recorded conveyance to grantee A with a covenant which is to affect all the adjoining land of the same grantor. If for some reason a later grantee, B, takes adjoining land by a recorded deed which does not contain the covenant, grantee A may lose a significant interest if the covenant is not enforced. Because neither party is at fault for failure to record, the problem must be analyzed in other terms. One commentator has suggested the following:

In reality . . . a satisfactory solution to this problem cannot really be achieved by resort to analysis of the "purpose" of the recording system. Rather, it would appear preferable to recognize that in these cases the recording system is often incapable (through no fault of grantee A) of giving constructive notice to grantee B without imposing upon him a very substantial title-search burden. Before a court can choose between grantee A and grantee B, several important questions should be answered. How great in fact is the burden on grantee B? How substantial are the interests of grantee A? Can the interests of grantee A be protected by means other than at the expense of grantee $\mathrm{B}$ ? $^{48}$

The Caitos' situation here parallels that of grantee A, and UCB's is similar to that of grantee B. The potential loss to UCB from its second trust deed was great-although UCB may have been adequately protected from loss by virtue of the first trust deeds it held agamst three other pieces of Caponi property ${ }^{49}$ At the same time, the Caitos' interests were at least as great as those of UCB. And the Caitos were no more careless with respect to the record than UCB was, if the Caitos were careless at all. The issue thus becoines whether UCB's imterest could in fact have been protected through resort to its multiple security, so that neither the Caitos nor UCB would have suffered because of a

47. Records are typically kept by a recorder of deeds office of all instruments affecting title, indexed chronologically and only under the names of grantee and grantor. Ryckman, Notice and the "Deeds Out" Problem, 64 MICH. L. REv. 421, 431 (1966). Therefore, the problem described in this paragraph arises because nothing in grantee B's "chain of title"-the record of conveyances and other instruinents affecting the particular property-will show A's interest (the burden on B's land in favor of grantee A). This is only one example of a variety of situations in which the most diligent search is unlikely to disclose the interest of a "stranger" to the title. See, e.g., Standard Oil Co. v. Slye, 164 Cal. 435, 129 P. 589 (1913); Sinclair v. Gunzenhauser, 179 Ind. 78,98 N.E. 37 (1912). There is also the problein that instruments executed by persons "within" the chain but either before or after taking title may not appear in the record chain of title. See H. TIFFANY, 4 Real Property § 1231 (3d ed. 1939).

48. Ryckman, supra note 47 , at 434 . For a discussion of the dilemma posed by a recording system that is not designed to cope with such probleins, see id. at 426-45. But see Philbrick, supra note 40 .

49. See note 3 and accompanying text supra. The court of appeal noted that the decd of trust to one of these properties was reconveyed before this action was filed and the other two deeds of trust were still in existence and constituted first liens on the two other pieces of property. 137 Cal. Rptr. at 844 n.3. There are not enough facts in the record, however, to determine this point definitely. 
fault in the record for which they were not responsible. Alternatively, the question is whether the interests of a party in UCB's position could otherwise be "protected" by imposing an easily borne duty of inquiry upon it. The court should at least have considered these issues.

The court's holding makes life easier for the inoneylender. It now simply can assuine a fact even when it knows the assumption may be both false and imprudent. The holding is particularly favorable to inoneylending institutions which easily can determine the true state of affairs. The holding puts an unreasonable burden on ordinary persons. They are less likely to be aware that they appear as principals or to know the legal significance of such appearance, and also are unlikely to be aware that a third party might rely to its detriment on an appearance in the record. ${ }^{50}$ Such a result hardly promotes the integrity of the recording systein. To achieve a more rational result, the court at a miniinuin should have recognized that the Caitos' status as sureties entitled thein to have the Bank of America note satisfied wholly from the Capon's' interest in the farin proceeds. UCB clearly had a duty to inquire whether the record state of title was accurate. The court also should have recognized that UCB's notice arguments were not an adequate basis for invalidating the Caitos' equitable liens.

\section{The Equitable Lien Claims}

The court correctly perceived that the Caitos' equitable subrogation claims potentially were barred to the extent they were liable as principals. ${ }^{51}$ It therefore stated that a strict application of equitable subrogation doctrine would preclude any recovery smce the Caitos appeared as principals on the Bank of America note. The court believed that such a result was not appropriate in this case, however, where "the record showed the Caitos and the Caponis to be tenants in coinmon . . .."52 Under these circumstances, the court concluded that the Caitos and Caponis were presumed to be equal cotenants equally liable on the Bank of America note. ${ }^{53}$ The court assumed that "UCB could

50. There are, however, some obvious difficulties with this argument. Not all cosigners are ordinary folk, and all lenders are not relatively more sophisticated. Also it may not promote simplicity, and inay not be sound pohicy for other reasons, to put any further burdens of inquiring into people's private affairs on the lending industry.

51. $20 \mathrm{Cal}$. 3d at 704-05, $576 \mathrm{P} .2 \mathrm{~d}$ at $47 \mathrm{l}, 144 \mathrm{Cal}$. Rptr. at 756 . There is no right to subrogation for a party primarily liable on the debt paid. Grant v. De Otte, 122 Cal. App. 2d 724, 265 P.2d 952 (1954). If this had actually been such a case, the court nced not have spent time on it, as it involved no new issue of law.

52. $20 \mathrm{Cal} .3 \mathrm{~d}$ at $705,576 \mathrm{P} .2 \mathrm{~d}$ at $472,144 \mathrm{Cal}$. Rptr. at 757.

53. Id. See Snider v. Basinger, 61 Cal. App. 3d 819, 823-24, 132 Cal. Rptr. 637, 639 (1976) (citations omitted):

The liability of cotenants, as between themselves, for the payment of liens against the common estate, is proportionate to their respective interests, and a cotenant relieving the 
not expect to benefit by an improved security position resulting from the Caponis' debt paid by the Caitos,"54 and reasoned that equitable subordination was a plausible claim to the extent UCB's security position was improved by the paynients made by the Caitos to Bank of America.

The court's discussion of equitable subrogation principles is plainly correct. Equitable subrogation is based on restitution and preservation of the priorities of junior creditors. By considering the situation in which a third inortgagee inakes a payinent to the senior henor, thereby improving the position of a second inortgagee, it becoines clear that notice is not an issue. There is no notice in such a case because the third mortgage is not of record at the time the second is created. Yet payment by the junior inortgagee entitles it to subrogation, to the extent of the payment made against the senior lien, on the ground that the second nrortgagee's position has been improved in a manner whicl it neitluer anticipated nor bargained for. ${ }^{55}$ The same result is reached when a cotenant pays a debt owed by the other cotenant. ${ }^{56}$

common property from a lien or charge for the joimt benefit of the tenants in common is entitled to an equitable lien by subrogation. [Citation.] For purposes of subrogation the paymg cotenant is not deemed primarily, but only secondarily, liable for his cotenant's proportion of the debt. [Citation.]'

54. $20 \mathrm{Cal}$. $3 \mathrm{~d}$ at $705,576 \mathrm{P.2d}$ at $472,144 \mathrm{Cal}$. Rptr. at 757 . The court states:

It is apparent from the foregoing the Caitos are foreclosed from asserting against the Caponis' sliare of the surplus fund, a priority claim for contribution unade from the Caito interest in satisfymg the demand of Bank of America. However, this does not necessarily foreclose the Caito claim based on moneys advanced by them to or on behalf of the Caponis for purposes of reducing the Bank of America note which, in turn, improved the security position of UCB.

$20 \mathrm{Cal} .3 \mathrm{~d}$ at 703, 576 P.2d at 470, $144 \mathrm{Cal}$. Rptr. at 755.

55. Brown v. Rouse, 125 Cal. 645, 58 P. 267 (1899). See 1 Miller \& STARR, supra note 36, at 446 .

56. Snider v. Basinger, 61 Cal. App. 3d 819, 132 Cal. Rptr. 637 (1976); Shaffer v. McCloskey, 101 Cal. 576, 36 P. 196 (1894). California precedent reveals that the entire debt inust have been paid, as it was in Shaffer. The rationale for such a rule, however, unust be that if a cotenant pays only part of a debt, subrogation then elevates the subrogee to an equal status with the principal creditor while part of the principal debt remains to be paid. This does in fact weaken the position of the principal creditor. Furtherniore, if the party who partially pays the debt is a surety, as the Caitos were lerein, it would be both unfair and irrational to elevate such parties to subrogee status so long as any sliare of the debt for which they are sureties remaims to be paid. As the Caitos argued, however, the situation is quite different when the entire debt is paid in fact and the accommodating cotenant asks for subrogation to the extent of its partial payment. The Restatenent of Restitution states:

Where obligation not fully discharged. Where property of one person is used in partially discliarging an obligation owed by another, and the balance of the obligation has not been discharged, the former is not entitled to be subrogated to the position of the obligee. Until the obligation is fully discharged, the obligee is himself entitled to enforce the balance of his claim, and the person whose property has been used in discharging only a part of the claim is not entitled to occupy lis position. If the balance of the clain is subsequently discliarged by the obhgor, lowever, the person whose property was used in discharging a part of the obligation is entitled then to be subrogated to the claitn to the extent that his property was used in discharging the claim.

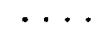


Even so, the court refused to give priority to any portion of the Caitos' claim based on the $\$ 6,000$ payment made to the Caponis to allow them to keep the Bank of America note current, or the claim based on the $\$ 17,500$ paid directly to Bank of America. As to the $\$ 6,000$, the court reasoned that UCB's security position was not improved by a paynient made before the junior lien was created. ${ }^{57}$ As to the $\$ 17,500$, the court concluded that the monies used to niake the payment accrued directly to Bank of America. The court thus rejected the trial court's apparent conclusion that all of the rents and profits during the period in question accrued to the Caitos as a partial offset for prior rental income that had been used to benefit the Caponis alone. ${ }^{58}$ The court reasoned first that the rents and profits had been assigned to Bank of America in the senior trust deed. Furthermore, the court held that it could not recognize the offset claim without giving "effect to secret or undisclosed equities existing between cotenants, contrary to established law."59

The court's disposition of the $\$ 6,000$ claim seems correct. Its conclusion, however, that the $\$ 17,500 \mathrm{~m}$ rents and profits accrued directly to Bank of America, was improper. This error is traceable to the court's premise that the Caitos were liable as primcipals for one-half of the Bank of America obligation. Because the Caitos were accommodation makers enly, the assignment of rents and profits arguably would apply only to those monies attributable to the primary obligor, the Caponis. This is a poimt the court failed to raise, but the issue easily could have been resolved by reference to the seinior trust deed. If Bank of America had a direct claim to only one-half of the $\$ 17,500$ rents and profits collected by the Caitos, the remaining $\$ 8,750$ was money that

A person whose property is used in partially discharging a secured obligation is entitled to an equitable lien upon the security although the obligation has not been fully discharged, but his interest in the security is subordinate to that of the obligee. It is, however, superior to the interests of the general creditors of the obligor.

RESTATEMENT OF RESTITUTION, Comment c at 655 (1937).

It would be a reasonable rule to allow subrogation for partial payment under such circumstances, at least when such payment is substantial, if the fourth element of the subrogation doctrine required by Shaffer - that there is no resulting injustice to the rights of others-is satisfied. As has been demonstrated, UCB was as responsible as if not more responsible than the Caitos for the fault in the rccord. The difference between Caito and Shaffer therefore is of little import. The Caito court itself states:

The instant case cannot be substantively distimguished from Shaffer. In each case cotenants of land were equally obligated on a debt secured by the whole of their land. One cotenant became obhigated to a second creditor, creating a junior lien on only that cotenant's share of the land. The other cotenant, unaware of the second security transaction, retired all or a part of the obhgation owed the first creditor, thereby eliminating or reducing the claim of lien senior to that of the second creditor.

20 Cal. 3d at 703, 576 P.2d at 471, 144 Cal. Rptr. at 756.

57. $20 \mathrm{Cal} .3 \mathrm{~d}$ at $707,576 \mathrm{P} .2 \mathrm{~d}$ at $473,144 \mathrm{Cal}$. Rptr. at 758.

58. Id. at 706,576 P.2d at 472,144 Cal. Rptr. at 757.

59. Id. at 706,576 P.2d at 473,144 Cal. Rptr. at 758. 
accrued to the Caitos and then was paid over to Bank of America. This analysis makes the discussion of equitable offset irrelevant as to the Caitos' $\$ 8,750$ interest. UCB's position was improved by this amount, and the Caitos' equitable lien should have been recognized accordingly.

\section{CONCLUSION}

The Caito court's refusal to allow the plaimtiffs to prove their accommodation maker status as agamst Bank of America and UCB was based upon a mistaken application of Civil Code section 2832. This error infected the remainder of the court's analysis and resulted in the plaintiffs' being prejudiced in the sum of at least $\$ 42,750$. As important, the court missed an opportunity to eliminate the ambiguous status of parties who sign an instrument as accommodation makers. The court failed to coinpel those parties in the best position to clarify the documents - the commercial lenders-to do so. As a consequence, the court, in an effort to safeguard the integrity of California's notice and recording scheine, ironically reached an inequitable result that only can have the opposite effect.

Sarah Toon Kavasharov*

\section{TAX}

Estate of Banerjee. ${ }^{1}$ The court held that where a nonresident of the United States who owns shares of stock in a non-California corporation ${ }^{2}$ dies leaving the stock certificates for such shares in California, the stock is subject to California inheritance tax. ${ }^{3}$ In doing so, the court expressly disapproved a recent contrary holding in Estate of Hall. ${ }^{4}$

At the timie of his death, the decedent in Banerjee was a resident

* A.B. 1967, Humboldt State University; J.D. 1979, Boalt Hall School of Law, University of California, Berkeley.

1. 21 Cal. 3d 527, 580 P.2d 657, 147 Cal. Rptr. 157 (1978) (opimion by the court).

2. "Non-California corporations" are corporations that are not organized under the laws of California, or that do not have their principal place of business or do the major part of their business in California. Id. at $530 \mathrm{n.1}, 580$ P.2d at $658 \mathrm{n} .1,147$ Cal. Rptr. at $158 \mathrm{n} .1$.

3. While intangible personal property of a deceased nonresident of the United States is often exempt from inheritance taxation, the exeinption apparently did not apply in this case. See note 10 infra.

4. 71 Cal. App. 3d 219, 139 Cal. Rptr. 336 (2d Dist. 1977). 
and national of Japan, and stock certificates for shares in several nonCalifornia corporations were held for him in an investment management agency account in San Francisco.

The applicable statute, Revenue and Taxation Code section 13303,5 provides that property subject to California inheritance tax includes "[a]ll intangible personal property in California belonging to a deceased nonresident of the United States, including all stock of a corporation organized under the laws of California or which has its principal place of business or does the major part of its business in California . . . The court rejected the argument, based on the maxim expressio unius est exclusio alterius, ${ }^{6}$ that the statute should be interpreted to exclude froin taxation stock in non-California corporations held by deceased nonresidents of the United States. Instead, the court took the view that by the language "[a]11 intangible personal property in California," the legislature intended to subject to taxation any stock where the stock certificates are physically present in California. The court argued that the reference to California corporations was included to make clear that stock in a California corporation is to be regarded as "in California" and hence subject to taxation, regardless of the location of the stock certificates. ${ }^{7}$

As a inatter of statutory interpretation, the decision seems sound. ${ }^{8}$ It does, lowever, leave open the possibility of multiple taxation by two or inore states of the United States where, for example, at the time of his death, a deceased nonresident of the United States owns shares in a

5. Cal. Rev. \& TAX. Code $\S 13303$ (West 1970).

6. "Mention of one thing implies exclusion of another thing." 21 Cal. $3 \mathrm{~d}$ at 532 n.2, 580 P.2d at 659 n.2, 147 Cal. Rptr. at 159 n.2.

7. Id. at 537-39, 580 P.2d at 663-64, 147 Cal. Rptr. at 163-64.

8. Until 1933, the California courts applied the doctrine of mobilia sequuntur personam (movables follow the person) to intangibles. $21 \mathrm{Cal}$. 3d at $536 \mathrm{n} .8,580 \mathrm{P} .2 \mathrm{~d}$ at $662 \mathrm{n} .8,147 \mathrm{Cal}$. Rptr. at 162 n.8. In that year, however, the United States Supreme Court held that stock owned by a British citizen and Cuban resident in a Cuban corporation, the physical evidences of which were in New York, was taxable under the United States Revenue Act of 1924 as property "situated in the United States." Burnet v. Brooks, 288 U.S. 378 (1933). The following year, the California Supreme Court, relying on Brooks, held that where a resident and citizen of Great Britain who owned stock in a California corporation died leaving the stock certificates in California, the stock was subject to California inheritance tax. Estate of McCreery, 220 Cal. 26, 29 P.2d 186 (1934). In 1935, the predecessor to $\S 13303$ was enacted. 21 Cal. 3d at 536, 580 P.2d at 662, 147 Cal. Rptr. at 162.

In light of this history and the language of the statute, the court's interpretation seens the most reasonable. One difficulty with such an interpretation, however, is that it permits double taxation by two or inore states, which appeared to be constitutionally prohibited at the time. See Estate of McCreery, $220 \mathrm{Cal}$. at 29, 29 P.2d at 187 (1934).

The policy behind the court's interpretation is apparently that where the evidence of ownership of intangible property is located within California, the intangible receives the protection of state law and should be taxable as if it were physically present in the state. See 21 Cal. 3d at 534, 580 P.2d at 661, 147 Cal. Rptr. at 161. 
corporation which was incorporated in a state that imposes an inheritance tax on the transfer of such shares, ${ }^{9}$ and the stock certificates for such shares are physically located in California. ${ }^{10}$

Weekes v. City of Oakland. ${ }^{1}$ The suprenne court held that the prohibition of California Revenue and Taxation Code section 17041.5 against inunicipal incoine taxes does not apply to the "einployee license fee" imposed by Oakland Municipal Code section 5-1.65. ${ }^{3}$ The Oakland levy applied to all those einployed within the city limits and was ineasured by the employee's "gross receipts." The court determined that the subject of the tax was properly characterized as the privilege of being an einployee rather than the income generated by its exercise. ${ }^{4}$ Since the ineasure was therefore a busimess tax, it was precisely within the city's home rule powers as provided by the California Constitution. ${ }^{5}$ The court thus avoided the issue of whether a nunicipal income

9. Cf. Tax Comm'n of Utah v. Aldrich, 316 U.S. 174 (1942) (upholding Utah tax on the transfer of shares in a Utah corporation owned by a nonresident decedent although the stock certificates for such shares had never been physically present in Utah).

10. See Marsh, Multiple Death Taxation in the United States, 8 U.C.L.A. L. REV. 69-70 (1961). Section 13851 of the Revenue and Taxation Code exeinpts intangible personal property from California inheritance taxation where the decedent was a resident of a territory or another state of the United States or of a country which provides a reciprocal exemption from its inheritance taxes of intangible personal property owned by a Cabifornia resident, thus avoiding any Cahfornia involvement in double taxation in those situations. CAL. REv. \& TAX. CODE § 13851 (West 1970). Japan, Banerjee's doinicile, apparently did not have any such rcciprocal arrangement with California. 21 Cal. 3d at 534 n.6, 580 P.2d at 661 n.6, 147 Cal. Rptr. at 161 n.6. sion).

1. 21 Cal. 3d 386, 579 P.2d 449, 146 Cal. Rptr. 558 (1978) (opinion by the court) (5-2 deci-

2. Section 17041.5 provides:

Notwithstanding any statute, ordinance, regulation, rule or decision to the contrary, no city, county, city and county, governmental subdivision, district, public and quasi-public corporation, inunicipal corporation, whether incorporated or not or whether chartercd or not, shall levy or collect or cause to be levied or collected any tax upon the income, or any part thereof, of any person, resident or nonresident.

This section shall not be construed so as to prohibit . . . any otherwise authorized hicense tax upon business ineasured by or according to gross receipts.

Cal. Rev. \& TAX. CODE $§ 17041.5$ (West 1970).

3. OAKLand Cal. Mun. Code $§ 5-1.65$ (1974).

4. $21 \mathrm{Cal} .3 \mathrm{~d}$ at 397,579 P.2d at 455, 146 Cal. Rptr. at 564. Both Justice Mosk and Justice Thompson attacked the inajority's thesis that the Oakland levy was not a inunicipal imcome tax because it did not reseinble the conventional income tax. In their view, the Oakland levy was an income tax regardless of its label simce the effect of the tax was to exact payinent of a certain percentage of the employee's incoine. Id. at 410, 579 P.2d at 463, 146 Cal. Rptr. at 572.

5. CAL. Const. art. XI, § 5(a) provides:

It shall be coinpetent in any city charter to provide that the city governed thereunder inay inake and enforce all ordinances and regulations in respect to municipal affairs, subject only to restrictions and limitations provided in their several charters and in re- 
tax is protected under the home rule provisions of the state constitution.

The court distimguished the Oakland levy from conventional imcome taxes on three grounds. First, income taxes are usually levied against net income-gross receipts less the costs of generating them. The Oakland levy, however, is measured by gross income. Second, gross income, for purposes of the Oakland ordinance, includes only employee compensation. Federal and state income tax schemes, by contrast, define "gross income" as mcluding not only "compensation for services," but also "interest," "rents," "royalties," and other iteins. Third, while a inunicipal income tax would apply to income of a city's residents whether or not earned within its boundaries, section 5-1.65 applies to Oakland-derived earnings, without regard to whether the recipients are residents of the city. The court attached great significance to these differences between the conventional income tax and the Oakland levy and dismissed as insignificant any differences between the conventional busmess license tax and Oakland's employee hicense fee. For instance, the court described the fact that section 5-1.65 encompassed all trades and professions, mstead of selected ones, and reached the individual employee, instead of his place of business, as a "novel" but otherwise unimportant change from the conventional license fee. Finally, the court observed that Government Code section 50026, which prohibits compensation-based municipal taxes that discriminate between residents and nonresidents, ${ }^{9}$ would be meaningless if Revenue and Taxation Code section 17041.5 prohibited all compensation-based municipal taxes whatsoever.

Justice Richardson, in a concurring opmion, rejected the majority's characterization of the Oakland measure as a business tax. In his view, the question to be decided was whether a municipal income tax was a "municipal affair" protected from state legislative interference by

spect to other matters they shall be subject to general laws. City charters adopted pursuant to this Constitution shall supersede any existing charter, and with respect to municipal affairs shall supersede all laws inconsistent therewith.

In Ex parte Braun, 141 Cal. 204, 74 P. 780 (1903), the California Supreme Court mled that business occupation taxes were a inumicipal affair within the meaning of this constitutional provision. Id. at $209,74 \mathrm{P}$. at 782 .

6. I.R.C. $\$ 61$; CAL. REV. \& TAX. CODE $\$ 17071$ (West 1970).

7. $21 \mathrm{Cal} .3 \mathrm{~d}$ at 395,579 P.2d at $453-54,146 \mathrm{Cal}$. Rptr. at 562-63.

8. CAL. Gov'T CODE $§ 50026$ (West Supp. 1979).

9. Under $\$ 50026$, any local entity otherwise entitled to enact a tax "on the privilege of earning a livelihood by an employee . . . on or measured by the earnings, or any part thereof, of any einployee, shall not impose any such tax ... when such employee is not a resident of the taxing jurisdiction, unless exactly the same tax . . . with the same credits and deductions, is imposed on the earnings of all residents of the taxing jurisdiction who are employed therein." The Code section was drafted in response to a so-called "commuter tax" enacted by the city of San Francisco in 1968. 
the California Constitution ${ }^{10}$ or whether the tax was a matter of statewide concern within state legislative authority. ${ }^{11}$ Justice Richardson argued that the Oakland tax, as a municipal income tax, did qualify for the "municipal affair" immunity. The state legislature therefore lacks the power to restrict such a tax, notwithstanding its desire to prevent an uneven distribution of tax burdens affecting intrastate coinmerce. ${ }^{12}$

The Weekes court, in refusing to characterize the Oakland employee hicense fee as an income tax, ignored the basic policies underlying the statutory prohibition of inunicipal incoine taxes. The purposes of the state legislature in restricting the right of local entities to tax individual incoune are threefold. First, the legislature felt that imposing a conibined federal, state, and local income tax burden on all mdividuals ${ }^{13}$ night render that burden prohibitive in the state. ${ }^{14}$ Clearly, an individual's tax burden is no different if a local measure is called an employee license fee rather than an income tax. Second, the legislature wanted to protect both state and local econounies; if municipal income taxes were enacted, businesses might change locations in order to avoid the tax burden (on themselves or on their employees). ${ }^{15}$ Here again, a business which chose its location on the basis of an employee salary tax would not decide differently simply because the local tax was labeled a license fee. ${ }^{16}$ Third, the legislature recognized that a municipal income tax inight result in inequity due to overlapping tax jurisdictions; an individual night be subjected to double local income taxation by his resident municipality and by his work municipality. ${ }^{17}$ The Oakland tax would not violate this third purpose because under the Weekes decision

10. Cal. Const. art. XI, $\S 5$.

11. See Bishop v. City of San Jose, I CaI. 3d 56, 460 P.2d 137, 81 Cal. Rptr. 465 (1969); Professional Fire Fighters, Inc. v. City of Los Angeles, 60 Cal. 2d 276, 384 P.2d 158, 32 Cal. Rptr. 830 (1963). For an excellent discussion of home rule problems in California, see Sato, "Municipal Affairs" in California, 60 CaLlF. L. REv. 1055 (1972).

12. 21 Cal. 3d at 407, 579 P.2d at 46 I-62, 146 Cal. Rptr. at 570-71 (Richardson, J., concurring). In a lengthy dissent, Justice Thompson gave his own analysis of the home rule issue and reached a conclusion contrary to that reached by Justice Richardson. In his view, the extraterritorial effect of the Oakland tax clearly inade it a inatter of statewide concern and therefore subject to state legislative restrictions.

13. The nearly all-encompassing reach of the employee tax in question is what really cquates this tax with a "normal" income tax.

14. Ch. 1265, § 2, 1968 Cal. Stats. 2388-89.

15. Ch. 559, \& 3, 1968 Cal. Stats. 1226.

16. Although the decision of location for a business is based upon inany considerations, including possibly the property tax rates and the amount of sales tax imposed, the presence of an "employee tax" at one possible site might make the difference, in the balancing of the total fiscal impact, in the decision to locate elsewhere.

17. Calif. Senate Fact Finding Committee On Revenue and Taxation, A Study Of The Feasibility Of Increasing State And Local Government Revenues From Selected TAXES 32-33 (I963). 
license fees would be assessed solely by an individual's work municipality.

The impact of a municipal income tax and that of an employee license fee are largely the same from an overall legislative policy standpoint. The differences in the form of the Oakland levy-excluding interest and capital gains income and denying deductions-do not affect its impact since the tax rate can be adjusted to compensate for these changes.

Weekes may only postpone the constitutional question to another day. In order to obtain approval of new municipal levies, cities will likely be under considerable pressure to nake employee payroll taxes seem inore equitable to the voters than the Oakland-type levy. ${ }^{18}$ For instance, nrodifications such as allowing deductions will probably be necessary to make the levy more progressive. Eacli such modification will make an Oakland-type tax look more like the incoune tax barred by section 17041.5, and will thus make it inore difficult for future courts to avoid the constitutional question.

18. Under Proposition 13, a recent amendment to the California Constitution, a supermajority vote of the residents of a community is necessary before new tax provisions may be enacted. CAL. ConsT. art. XIIIA, $\$ 4$ provides: "Cities, counties and special districts, by a twothirds vote of the qualified electors of sucl district, may impose special taxes on such district, except ad valorem taxes on real property or a transaction tax or sales tax on the sale of real property within such City, County or special district." 